\title{
From environmental stress to spatial expulsion - rethinking concepts of socio-spatial exclusion in later life
}

\author{
BY AnNa Wanka ${ }^{1}$, Thibauld Moulaert ${ }^{2} \mathcal{E}$ Matthias Drilling ${ }^{3}$
}

\begin{abstract}
Gerontology has a longstanding tradition of researching the relationship between older adults and their socio-spatial environments. However, environmental gerontology often shares a positivistic understanding of space as either a "prosthetic" or a stressor and consequently searches for the "best fit" between a person and their environment. In this article, we argue for a stronger theoretical corpus on social and territorial exclusion in later life by exploring concepts from urban and environmental sociology, as well as examining the usefulness of these concepts for gerontological thinking. In doing so, we discuss trans-European research traditions beyond the hegemonic body of Anglo-Saxon literature. In conclusion, we discuss how gerontology and sociology might exchange ideas in order to build a stronger theoretical background on the relations between age, space and exclusion.

Keywords: environmental gerontology, spatial exclusion, urban sociology, critical gerontology, age-friendly cities and communities

${ }^{1}$ Anna Wanka, Goethe University Frankfurt on the Main, Department for Social Pedagogy and Adult Education, Research Training Group "Doing Transitions", Germany

${ }^{2}$ Thibauld Moulaert, Université Grenoble Alpes, CNRS, Sciences Po Grenoble, School of Political Studies, PACTE Social Sciences Laboratory, 38000 Grenoble, France

${ }^{3}$ Matthias Drilling, University of Applied Sciences, School of Social Work, Institute for Social Planning and Urban Development, Switzerland
\end{abstract}


International Journal of Ageing and Later Life

\section{Introduction}

Urbanisation and demographic change constitute two of the major developments of the $21^{\text {st }}$ century. In 2014, 74\% of Europe's population lived in urban areas (United Nations, Department of Economic and Social Affairs, Population Division 2018), and by 2030, at least a quarter of that percentage will be aged 60 and over (Handler 2014). In this process, older urban residents are becoming more ethnically and socio-economically diverse (Koceva et al. 2016), but attention is also called to achieve a better understanding of how physical and social environments influence ageing in rural and remote communities (Keating et al. 2013). Hence, there is a need to systematically discuss the relations between age, space and exclusion (Moulaert et al. 2018).

In reference to Walsh, Scharf and Keating, spatial exclusion can be understood as:

...a complex process that involves the lack or denial of [spatial] resources, rights, goods and services as people age, and the inability to participate in the normal relationships and activities, available to the majority of people across the varied and multiple domains of society. It affects both the quality of life of older individuals and the equity and cohesion of an ageing society as a whole (adapted from Levitas et al. 2007). (Walsh et al. 2017: 83)

To understand and counteract the risk of spatial exclusion in later life, we need to strengthen theory in gerontology in general (Estes et al. 2003) and, more particularly, in the specific domain of spatial exclusion in later life (Walsh et al. 2017). In fact, a longstanding tradition of research on spatial living conditions and place perceptions of older adults does exist in gerontology. Over the past 50 years, environmental gerontology (EG) has specifically emerged as a distinct subfield of gerontology that focuses on the description, explanation and optimisation of the relationship between older adults and their socio-spatial environments (Wahl \& Weisman 2003). The growing popularity of this field is due not least to the attention that the policy concept of "ageing in place" has received since the 1990s. The notion of ageing in place suggests that older people should stay in their familiar environments despite the potential needs for care that may arise and that they should not be forced to move into retirement homes. In line with supporting independence and autonomy in older age, 
another major argument for this policy is that it decreases costs for the health care system (Wiles et al. 2012).

Despite having emerged from a care-focused discourse, ageing in place has ignited a debate about age-friendly cities and Philipson has called for a new "environmental gerontology" that would put the changing realities of the urban experience at the forefront of its research agenda (Phillipson 2004). The focus on cities here can be explained by the fact that the older population is growing more rapidly in urban areas, but also by the finding that differences between urban and rural areas persist regarding informal and family care giving. For instance, older adults in rural environments are still more likely to be taken care of by their social networks and are less likely to be living in an institutional setting (McCann et al. 2014). The focus on cities might also illustrate what has been termed a "spatial turn" across disciplines (Warf \& Arias 2009).

The World Health Organization (WHO) thus launched a number of policy initiatives in age-friendly cities throughout the 2000s, with active ageing as the core element (Buffel et al. 2012). In 2005, they initiated the "Global Age-Friendly Cities" project involving 33 cities, producing a "Global Age-Friendly Cities" guide (WHO 2007) that has been used as a flexible, yet influential, checklist for policy-makers (Plouffe et al. 2016), which contrasts with the critical interpretation of a "static" vision of age-friendliness (Keating et al. 2013). Even though analysis of the literature suggests that the WHO's age-friendly cities framework is only one model that appears among a variety of potential ones (Lui et al. 2009), and even though it has been applied in different forms and with different foci (Moulaert \& Garon 2016), the main idea of promoting active ageing through age-friendly environments has spread across policies in various places of the world ${ }^{1}$. However, it is not only the urban population in general that is becoming more diverse but also the older population in particular. For researchers and policy-makers alike, questions arising from age-friendly guidelines and standards for cities remain: do concepts of age-friendly cities consider all older individuals? Can they cater to the diversification of older age? Which new mechanisms of socio-spatial exclusion emerge against the backdrop of these developments?

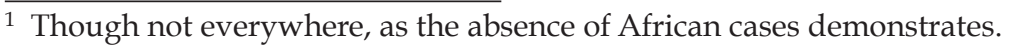


International Journal of Ageing and Later Life

In this article, we argue that EG can learn a lot by exploring theory from other disciplines and regional research traditions. Many disciplines other than gerontology - ranging from sociology to human geography - have advanced theories about the environmental aspects of social exclusion.

Hence, this article is organised into three parts: in the first and second parts, we discuss theoretical concepts from gerontology (2) and sociology (3) that can be - or have been - fruitful for the analysis of later-life exclusion. Finally, in the third part, we discuss what gerontology and sociology can learn from each other about socio-spatial exclusion.

\section{Socio-Spatial Exclusion from Gerontological Perspectives}

EG has a long tradition of describing, explaining and - with gerontology being historically an applied field of science, this must be emphasised working to optimise the relationship between older adults and their socio-spatial environments. Beyond emphasising the role of the physical environment, it acknowledges the entanglement of the physical, social, organisational and cultural aspects of environments.

In their reflexive literature review of environmental gerontological research, Wahl and Weisman (2003) differentiate between gerontological theories that research (1) maintenance of, (2) stimulation through and (3) support from the environment (based upon Lawton's three basic functions of environments, 1989). However, perhaps due to the still widespread deficit-oriented image of ageing, the most influential body of research in this field focuses on the support function of environments. In 1964, Lindsley coined the term "prosthetic environment", and in 1973, Lawton and Nahemow established their competence-press model. This "environmental docility hypothesis" states that people are more independent of their environments when they have more resources at their disposal. Socio-personal and socio-spatial resources thus complement each other, ideally holding a balance like a pair of scales. This assumption holds true for basically every age group. It does, however, gain importance in older age due to the loss of socio-personal resources that the authors assume come with age. In older age, so the hypothesis goes, the "environmental press" increases. Environmental press is thus a relational concept, taking into account both environments and personal capacities. Interestingly, 
this increase in press does not only imply effects on the quality of life but also influences behaviour. A certain degree of press, particularly when equipped with sufficient resources, can lead to positive affect and adaptive behaviour, whereas too much press in relation to competences triggers negative affect and maladaptive behaviour, such as withdrawal. Similarly, the concept of person-environment-congruence (Carp 1987; Kahana 1982) departs from the idea of a different level of congruence between a person and an environment, depending on the resources and competences. Going further than Lawton's model, congruence is based upon not only competences but also preferences and perceptions.

Today's EG research is still heavily based upon these "classics" - or, as Wahl and Weisman put it: "it is not easy to identify much innovation in recent EG research" (Wahl \& Weisman 2003: 621). Wahl and Oswald are among the most influential thinkers continuing Lawton's legacy. In 2006, Wahl and Lang developed the Social-Physical Places Over Time (SPOT) model, combining both the notion of physical, outside and social, affective space with a life course perspective ${ }^{2}$. The SPOT model claims that social-physical agency decreases throughout the life course, due to decreasing personal competences, but the social-physical sense of belonging increases. This model was further developed by Wahl and Oswald (2010) into the concept of person-environment (P-E) fit. P-E fit describes the relationship between place valuation, belonging and attachment on the one hand, and spatial agency, behaviour or appropriation on the other hand, with identity, autonomy and well-being (Figure 1).

In contrast to early environmental gerontologists, Wahl and Oswald emphasise the significance of subjectivity and the personal meaning of an environment for a person (or group) and the role of personal agency in intervening and acting on one's environments. This thus "empowers" older adults and frees them from their role as "victims" of their environments, responding to the post-positivist critique that sees most EG models as overly functional. A lot of research has been conducted on both the dimension of belonging and spatial agency already, but Wahl and Oswald try to bring both perspectives together. However, despite their

\footnotetext{
${ }^{2}$ A similar model is used by Keating and her colleagues to discuss the large variations in ageing in rural areas (Keating et al. 2013).
} 
International Journal of Ageing and Later Life

Figure 1. Person-environment fit (Wahl \& Oswald 2010).

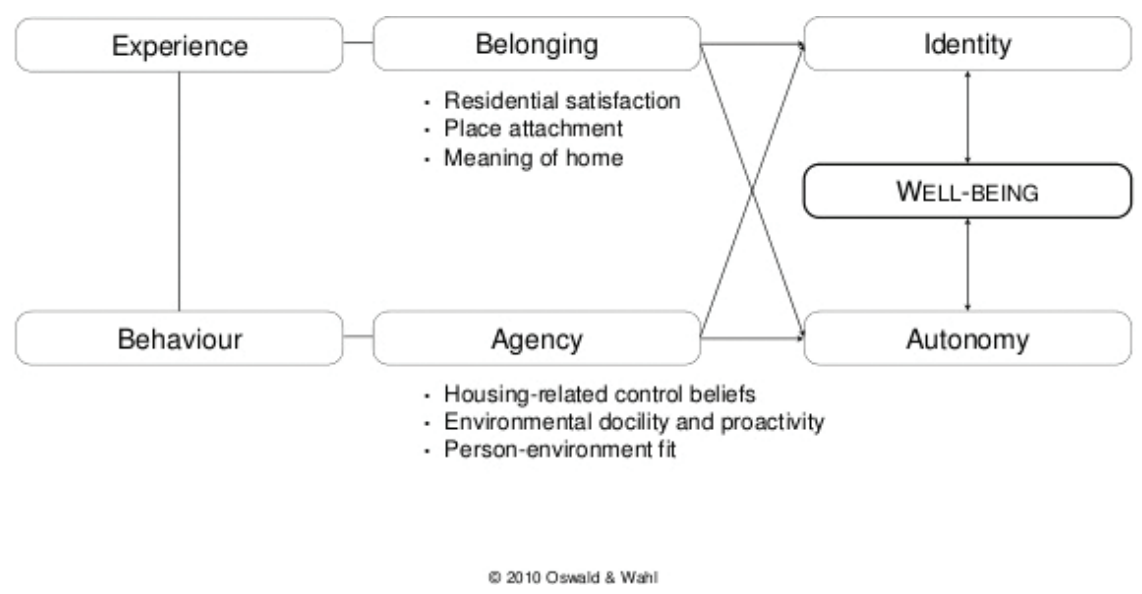

consideration of the subjective assessment of one's environment, such model approaches tend to stay positivist and have been criticised for trying to explain, but not understand, the relationship between older people and their environments.

Research on spatial belonging or place attachment emphasises exactly these internal (cognitive, affective, perceptual) processes that lead to a subjective feeling of being included or excluded from one's environment. Much of this research stems from the field of developmental psychology and approaches the topic of place attachment from a perspective of cognitive and affective development. However, various concepts do consider agency, behaviour and active coping strategies. One of the earliest representatives is Havighurst (1976), who framed the establishment of a satisfactory physical living arrangement as one of six central developmental tasks in late maturity (60 years and older). Similarly, Rowles and Watkins (2003) conceptualised a life course model of environmental experience. In their experiential phenomenological research, they analyse the dynamic nature and the development of the P-E relationship across the life course 
and how the development of this relationship entails the formation of new competences. One of the core competences for building relationships with places is the ability to "make places," and this evolves and changes across the life span (Rowles \& Watkins 2003).

Whereas Rowles and Watkins see a positive assessment of one's living environment as the outcome of successful place-making practices (or successful flexibility in Havighurst's perspective), Golant (2015) frames appraisal processes as influencing factors for coping strategies in his model of residential normalcy. Thus, assimilative (cognitive) coping cannot be separated from assimilative (action) coping. Successful coping then leads to successful ageing.

These scientific understandings, although based upon sophisticated research, reveal the underlying norms of EG: going outdoors is "good," as it is beneficial to one's health, and staying at home is "bad" and, hence, can hardly ever be voluntary. All activities suggested by seminal gerontology (Havighurst 1954: 311) implicitly require going out, be it either for women ("a discussion group for a housewife whose large family has grown up") or for men ("a men's brotherhood in the church for a man who has worked on a lathe"). Motivations for staying at home are hardly ever researched, leading Künemund and Kaiser (2011) to reason that staying at home is only then legitimate when a person is physically impaired, or bound to the home by care obligations, or hindered from going out by physical barriers.

Beyond P-E fits, spatial agency and place attachment, some research in EG also considers environmental justice. Environmental justice research focuses on the intersectionalities between age and socio-economic status (and, sometimes, gender and ethnicity; cf. Wanka 2018b) and how these lead to multiple jeopardy (cf. Norman 1985) in regard to socio-spatial exclusion. Aiming to understand social inequalities in relation to space, many ethnographic and qualitative studies have adopted a neighbourhood approach, choosing case sites based on their level of deprivation (e.g. Buffel et al. 2012; Day 2010; Holland et al. 2007; Scharf 2002). These studies depart from a socio-economic, sometimes political, understanding of exclusion as a starting point, and research how older adults deal with and live in deprived neighbourhoods. Some of the most sophisticated research in the field of gerontological environmental justice 
International Journal of Ageing and Later Life

research stems from Chris Phillipson and colleagues who had early on called for a "new environmental gerontology" that puts urban areas at its centre (Phillipson 2004). He critically discusses how dichotomies are produced in cities, dividing older adults into the "elected" who benefit from globalisation and the "excluded" who suffer from rejection and marginalisation in this process (Buffel et al. 2018; Phillipson 2007). However, by focusing on urban areas such perspectives neglect the fact that globalisation affects not only cities but also a wide variety of regions and risk unintentionally neglecting ageing in suburban (Marchal 2017) or rural areas (Keating et al. 2013).

More recently, gerontologists working in this field have also considered processes of gentrification from an environmental justice perspective (cf. Wiles et al. 2012). Gentrification can be defined as "the process by which higher income households displace lower income residents of a neighbourhood, changing the essential character and flavour of that neighbourhood" (Kennedy \& Leonard 2001). Keating and colleagues argue that similar replacement processes also take place in rural areas. "The history of Robertsville [a bucolic village] illustrates how a changing place can exclude long-term residents while at the same time attracting those for whom aging in a new place is a preference" (Keating et al. 2013: 329). While place is the location of exclusion, the process of exclusion is a dynamic of the personal and the environment. However, whether it is in such a rural area or in a deprived urban neighbourhood, a recurrent aspect of ageing is the long-term stay of some inhabitants.

How do these different strands of environmental gerontological literature understand the relationship between age, space, and exclusion? Gerontological literature on the support function of the environment frames age as a particularly vulnerable stage of life in which people tend to lose resources and are, thus, more dependent upon their environment. Space, in this regard, has the function of a "prosthetic" (Lindsley 1964) or a stressor (Lawton \& Nahemow 1973): if it works as a prosthetic, older adults can remain autonomous and satisfied; if, instead, the environment puts additional barriers in their way, their quality of life will decrease. A certain level of environmental stress can lead to positive adaption; too much of it, however, will lead to maladaptive behaviour, such as withdrawal. This definition of space resembles that of the "container model 
of space." Understanding space as a container implies that "humans cannot construct anything without being first in place - that place is primary to the construction of meaning and society" (Cresswell 2004: 32). Exclusion, from this perspective, would be the result of it being impossible to autonomously use or be part of a certain environment, for example, move around in it, and hence lead to withdrawal from this place.

Gerontological literature on environmental justice, similarly, frames age (or, more exactly, duration of residence) as a risk factor and the environment as a space of possibilities, which puts older adults at lower or higher risk of being socio-spatially excluded. This literature broadens the perspective on exclusion from the direct use of the environment to manifold dimensions, like exclusion from social relationships, exclusion from important infrastructures, exclusion from participation in political processes and so on.

Gerontological literature on place attachment, finally, is concerned with the subjective feeling of exclusion from one's environment. From this perspective, coping - both practical and cognitive - with environmental change is seen as crucial for spatial inclusion and exclusion in later life (Golant 2015). A person can, however, be able to use a place but still feel excluded from it (cf. Wanka 2018a). From this perspective, age and space are co-constitutive, with space being subject to human "place-making" practices, with the ability to do so evolving across the life course (Rowles \& Watkins 2003).

When contrasting these gerontological approaches, we can conclude that socio-spatial exclusion is framed by EG as:

- Relative: resulting from a lack of capacity to use places due to agerelated decline in resources.

- Structural: resulting from a lack of access to important infrastructure.

- Subjective: based on personal assessment.

In the next section, we discuss literature from (urban and environmental) sociology by questioning how it understands age, space and exclusion. Finally, we will contrast both perspectives in order to see what gerontology can learn from sociology when researching socio-spatial exclusion in later life, and vice versa. 
International Journal of Ageing and Later Life

\section{Socio-Spatial Exclusion from a Sociological Perspective}

Space has been of concern to sociological enquiry for a long time now, and it has a particularly long research tradition when it comes to cities. One of the most influential early scholars, Simmel, as long ago as 1903, highlighted the significance of urban life for forming the social character of its inhabitants (Simmel 2010). Urban and environmental sociology is concerned with how socio-spatial relationships are formed, how spatial inequalities develop and how places shape the identities and lifestyles of their inhabitants.

Sociological research on the person-place relationship and socio-spatial exclusion has focused on the following areas of research: (1) socio-spatial segregation, (2) environmental effects on identity building and (3) the production of space.

Research on socio-spatial segregation has its roots in the early Chicago School, which perceived cities as "integration machines," although today they are mainly said to have lost this function (Geiling 2003). Social segregation, replacement and even expulsion (Sassen 2014) have taken its place in today's cities. The "spatialisation" of social inequalities points to the phenomenon that disadvantaged populations tend to live in disadvantaged areas, and vice versa (Savage et al. 2003). This spatialisation, in turn, affects the life chances of these populations, reproducing social inequalities (Häußermann \& Siebel 2000). Residential segregation is defined as all those processes that eventually lead to internally homogenous spaces that can be based on different social criteria such as socio-economic status or ethnicity (Löw et al. 2007) - however, in a free housing market, income plays an essential role in distributing people across the city (Keim \& Neef 2000).

Much of the early sociological and geographical work makes use of the container model of space. For instance, a "vicious circle" between socio-economic and spatial deprivation can be portrayed as follows: persons with little income move to areas where rent is low, and the rent is most likely low because little public (i.e. green spaces and care facilities) and market infrastructure (e.g. shops) exists in these areas. If the residents of an area have low income, even less infrastructure (e.g. shops) will be provided by the market, which again can lead to a selective outflow of people (Friedrichs 1988). Gentrification research has stressed the role of 
cultural capital (Bourdieu 2015 [1992]) in addition to economic capital, but the "container thinking" has been preserved.

Research on cultural factors in socio-spatial segregation led to a focus on the relationship between one's residential environment and one's identity - and opened up the container thinking to a more post-positivist perspective. From a general sociological or geographical perspective, the neighbourhood is a key element of identity (Authier et al. 2006). Taking the case of a French suburban neighbourhood, Marchal (2017) refers to the work of Di Méo to clarify the concepts of space, territory and place (Di Méo 2007; Di Méo \& Buléon 2005). At a macro level, space refers to anonymous and globalised trends; at a meso level, territory offers opportunities for collective action and identities; at a micro level, place consists of informal, experienced and sensitive personal aspects.

Through these levels, whenever (more or less) homogenous groups form, they must set up borders. The same is true for the spatial dimension. While this can be done by material means - actual walls or fences can be found in gated communities - it can also be done by symbolic means. The case of Villa Vermeil de Biscarrosse (in southwest France), a private gated community for seniors inspired by the American model of retirement communities, is of particular interest here. The community had to open its gates to younger generations in order to counter housing vacancies. However, the older residents considered such imposed intergenerational cohabitation as a betrayal of their original choice to move there (Vuaillat \& Madoré 2010). Gerontological segregation research from the US has long focused on "gated communities"; however, not as a means of analysing social exclusion (cf. Townsend 1979, 2002), but rather as a place to create and experience collective solidarity and the same shared activities, similar to a trailer park (Hoyt 1954).

The symbols that are being used to evoke identification or alienation help to include and exclude groups on a more subtle level, but nevertheless produce and reproduce inequalities. One example is the use of local gossip as a form of distinction between "the established" and "the outsiders," through the process of civilisation using "we-images" (Elias \& Scotson 1994). Such staging processes can also facilitate place identity and place attachment among those that are included; however, they evoke feelings such as alienation among those excluded. Conversely, Sampson (2009) 
International Journal of Ageing and Later Life

highlights the psychological effects of symbolic segregation through visible disorder, deploying Goffman's (1986 [1963]) concept of stigma together with Kelling and Wilson's (1982) "broken windows" theory of urban decline. Werthman and Piliavin (1967) were two of the first urban sociologists to use the concept of stigma in a socio-spatial way. Their "ecological contamination hypothesis" implies that the stigma of a neighbourhood can stain persons and their identities - they are identified with their area by themselves and by others. Similarly, Wacquant elaborated on an analytic framework termed "territorial stigmatisation" that weds Goffman's concept of "spoiled identity" with Bourdieu's theory of "symbolic power," constituting "advanced marginality" in the dualising metropolis. The framework of territorial stigmatisation aims to describe how spatial taint affects its residents and how they cope with it (Wacquant et al. 2014). Wacquant has also analysed the coping strategies of residents of disparaged neighbourhoods. He differentiates between strategies that submit to and reproduce, and those that rebel against, spatial stigma (Wacquant 2011). Which strategy is being adopted by whom depends on the position and the trajectory in social and physical space, therefore varying with class, age, life course, housing tenure and duration, ethnicity, and so on (Figure 2).

One of the strategies that is particularly important to discuss is that of retreat into the private sphere. Pereira and Queirós (2014), for example, found this strategy to be deployed by residents of a public housing estate

Figure 2. Strategies to cope with territorial stigma (Wacquant et al. 2014).

Table 1. Distribution of strategies designed to cope with territorial stigma (source: Wacquant, 2011b).

\begin{tabular}{ll}
\hline Submission $\leftarrow$ & $\rightarrow$ Recalcitrance to resistance \\
\hline $\begin{array}{l}\text { 1-dissimulation } \\
\text { 2-mutual distancing and elaboration of } \\
\text { microdifferences }\end{array}$ & $\begin{array}{l}\text { 6-studied indifference } \\
\text { 7-defense of neighborhood (individual or }\end{array}$ \\
$\begin{array}{l}\text { 3- lateral denigration } \\
\text { 4- retreat into the private (family) sphere } \\
\text { 5-exit }\end{array}$ & 8-stigma inversion (hyperbolic claiming) \\
\hline
\end{tabular}


in Porto, Portugal. They found that residents react to the stigma of their living environment by restricting their public relationships and limiting outdoor activities to subsistence activities, and they refer to this strategy as "subsistence sociability" and "focused avoidance." Although he does not himself refer to Wacquant's framework, Marchal explains how a typical French suburb in the northeast of France is experienced as a "village in the city," in reference to the Young and Willmott ethnography of Bethnal Green, London (Young \& Willmott 1957). While housing is often considered as a central element of identity for older persons, Marchal demonstrates that the identities of older residents are more linked to their neighbourhood than to their personal housing. The territorial stigma is transformed here from a "retreat into the private sphere" to the "defence of neighbourhood." Avoiding the neutral/impersonal concept of "space," Marchal prefers the notion of "territoire" as a place for shared and lived experience, collective identities based on inhabitants' initiatives and/or informal routines situated in a clear manner (at the chemist's, on the corner shop, etc.; Marchal 2017) ${ }^{3}$. We can thus see that territorial stigmatisation is not a condition, but rather a form of "action through collective representation fastened on place" (Wacquant et al. 2014: 1278), thereby advancing the empirical understanding of its role in producing urban inequality and marginality.

Beyond segregation and identification, spatial exclusion is concerned with the production of space itself. According to Lefebvre (1991 [1974]), space is produced through spatial practice, representational space and representations of space. Spatial practice refers to the everyday practices and perceptions with which ordinary people encounter and use space. It comprises their daily routines, the places they avoid and the ways they appropriate places and attach a feeling of home to them. Representational space refers to passively, instead of actively, experienced space - the way people subconsciously read and understand the signs and symbols in space (e.g. through signs of disorder that might symbolise crime in a certain area; cf. Kelling and Wilson's "broken windows hypothesis," 1982).

\footnotetext{
3 The French notion of "territoire" could to some degree be compared to the Anglo-Saxon term of "community," which is often used in age-friendly city and community policies. However, "territoire" also points to institutional policies covering local areas.
} 
International Journal of Ageing and Later Life

Representations of space are, finally, the conceptualisations of space made by planners, scientists and policy stakeholders. They may take on physical form in terms of maps, plans, models and designs. Such representations are laden with ideologies and have a substantial role and specific influence in the production of space. With regard to ageing, concepts of age-friendly cities, like the WHO concept (Lui et al. 2009), constitute representations of space.

Lefebvre's (1991) claim that all citizens should have a "right to the city" implies that all people should participate in the production of space in all three dimensions. They should be able to appropriate space both practically and cognitively, and they should be allowed to participate in decision-making and in the representation of space (Purcell 2003).

How do these perspectives from sociology understand age, space and exclusion, and how does this differ from gerontological concepts? Sociological research on socio-spatial segregation bases exclusion on the spatialisation of social inequalities, that is, the processes that lead to disadvantaged populations living in deprived areas (Savage et al. 2003). Space, in this conceptualisation, is viewed as a "container," but at the same time as dynamic: it changes with the people who live in it. These processes can generally be traced back to socio-economic inequalities. Hence, wealthier people can afford to live in areas with better infrastructure, wealthier neighbours, less crime and a better "image." Whereas research has proceeded from merely looking at economic inequalities to also considering, for example, ethnicity, age is hardly ever considered by sociologists. Urban and environmental sociology still seems to be age-blind. However, this strand of research has influenced gerontological research on environmental justice in particular (cf. Scharf 2002), as well as research on the displacement of older, economically deprived persons through gentrification processes (cf. Wiles et al. 2012).

Sociological research on environments and identities has emphasised how living in deprived areas may lead to stigmatisation and hence "spoil" identities (cf. Sampson 2009; Wacquant et al. 2014; Werthman \& Piliavin 1967). In this sense, exclusion refers to a cultural status of disesteem based upon the image of a person's residential area. Space matters in its perception and representation - however, not primarily that of the people living in it, but particularly that of those living outside of it, as Elias and Scotson 
(1994) express by distinguishing "the established" and "the outsiders." Again, age is not particularly considered in these approaches. However, by applying the general logics of stigma to later life, it can be assumed that the "stains" of an environment will be more intense the longer a person has lived in this environment. Inspired by sociology, such an argument is recurrent in Phillipson's perspective about cities in a globalised world (2007) and is also described in rural areas (Keating et al. 2013).

Research on the production of space, finally, stresses the notion that space is constituted through spatial practice, representational space and representations of space. Space is, from this perspective, not something that pre-exists, but something that is constantly co-constructed by various actors with varying levels of power. It draws attention to the questions regarding which places are used or not used by whom, how they are perceived by whom, and who represents them in which way. Exclusion is, from this perspective, multi-dimensional, comprising the use, perception and representation of space. Anyone who is excluded is hence neither able to actively or passively appropriate space, nor to take part in the decisionmaking and representation of space. The latter, in particular, entails an emphasis on power relations that unfold in spatial mechanisms of social exclusion. Even though age has not been considered in Lefebvre's theoretical concepts, his call to the "right to the city" has been taken up by gerontologists as a flagship for an alternative discourse on age-friendly cities (cf. Phillipson 2011; Buffel et al. 2012). However, critical gerontologists have not yet considered the threefold and complex Lefebvrian conception of space (Moulaert et al. 2018), but prefer to focus on "giving a voice" to "the most excluded" by promoting participatory methods in social sciences (Buffel 2015) and in urban planning and design (White \& Hammond 2018). Furthermore, representations of space comprise not only decision-making but also spatial conceptualisations made by planners, scientists or policy stakeholders that shape representational spaces (images and perception of environments) and therefore occupy a crucial role in the production of space and spatial exclusion. If older people were able to appropriate space both practically and cognitively, and were allowed to participate in the decision-making and representation of space (Purcell 2003), such an agenda would support the WHO's model of "agefriendly cities" by promoting the "social participation" of older people. 
International Journal of Ageing and Later Life

This has been translated into multiple ways of consulting older people, including seats on local or central steering committees reserved for seniors, and many authors call for intensification of such participatory approaches supporting a "citizenship- and rights-based narrative of ageing" (Buffel et al. 2018: 288). However, one may doubt the real access of older people to decision-making and processes of power. Can they really and successfully oppose the decisions of local authorities? Even if we can consider ourselves as inspired by "public sociology" when observing and supporting local "age-friendly" practices (Moulaert \& Garon 2015), we, as researchers, must ourselves be careful about how we represent age, space and socio-spatial exclusion, particularly when we use existing representations like age-friendly cities.

Summarising urban and environmental sociological perspectives, we can conclude that socio-spatial exclusion is framed as:

- Based upon socio-economic status: resulting from income inequalities and leading to socio-spatial segregation.

- Cultural: resulting from the reputation and labelling of an environment and leading to stigma and "spoiled" identities.

- Multidimensional: comprising active and passive appropriation, as well as participation in the representation of space.

Conclusion: What can Gerontology and Sociology Learn from Each Other about Socio-Spatial Exclusion?

In the two previous sections, we tried to show how gerontology and sociology have conceptualised the relationship between age, space and exclusion thus far.

Both sociology and gerontology have longstanding traditions of researching the spatial mechanisms of social exclusion. The most obvious differences between them might be that theoretical concepts from urban sociology hardly ever consider age explicitly, nor do they adopt a life course perspective, and many (though not all) gerontological accounts neglect power relations. However, there are also some connections to be made between the two disciplines. In particular, we can find (infra-) structural definitions of exclusion in both disciplines, pointing to lack of (access to) important infrastructure in certain residential areas. 
Rethinking concepts of socio-spatial exclusion in later life

This lack may particularly affect older adults, as their action scope tends to be smaller than that of younger adults, and they usually spend more time in their immediate residential environment (cf. Wahl et al. 1999). Whereas sociological concepts of socio-spatial segregation often do not consider age, environmental justice accounts from social gerontology depart from a socio-economic understanding of exclusion as a starting point, but then focus on older adults and how they deal with living in deprived neighbourhoods. In doing so, they - in accordance with sociological accounts - also extend the notion of exclusion to comprise service exclusion, exclusion from social relationships, economic exclusion and civic exclusion. The latter is often linked to the call for the "right to the city" (Lefebvre 1991) and is used to legitimise research on how older people are able or unable to participate in decision-making processes, thus ultimately affecting their residential environments (cf. Buffel et al. 2012).

This leads to the preliminary conclusions that we can draw from both disciplines, namely that (1) inequalities are intersectional and (2) exclusion is multidimensional and (3) processual. Intersectionality refers to overlapping systems of advantage or disadvantage, or as Crenshaw (1989) puts it, systems of oppression and discrimination, which certain groups face based on their location at the intersection of gender, age, ethnicity, sexuality, economic background and so on. These intersections are, using the words of sociologist Emile Durkheim, "greater than their sum." Both gerontology and sociology have considered such intersections, for example, in concepts like "double jeopardy" (c.f. Dowd \& Bengtson 1978; Baykara-Krumme et al. 2012) - mostly, however, from a deficit perspective. Often, such accounts ask about how intersecting personal attributes that are defined as risk factors lead to an increased risk of socio-spatial exclusion. Enriching such accounts with notions of "territorial stigma" (Wacquant et al. 2014), however, allows for treating one's environment as an additional attribute and might re-shape such questions to ask how for example - being an older migrant woman living in a deprived area affects identity-building processes and images of ageing for this group of people. For his part, Marchal (2017) illustrates how ageing in a suburb can come with increased risk of exclusion, but only under certain circumstances. He illustrates this with the example of an older widow, who lives on the upper slope of a hill, while shops and public transport are "only" 
International Journal of Ageing and Later Life

200 meters below and who receives little help from neighbours. In her case, space becomes a driver of exclusion.

Using analogy, we can frame socio-spatial exclusion as being multidimensional, and these dimensions can also intersect. In its most basic form, spatial exclusion may refer to the lack of access to a certain place. However, socio-spatial exclusion can comprise a lack of access to certain shops and services, such as public transport - for either infrastructural reasons or reasons of economic affordability - but it can also comprise a lack of access to relationships with friends and neighbours - both face-to-face and online, depending on online infrastructure - and can also entail barriers to civic participation within or concerning the neighbourhood. These dimensions of socio-spatial exclusion can intersect, but do not have to. For example, in her analysis of a deprived area in Vienna, Austria, Wanka (2018a) has shown how very economically disadvantaged older residents have hardly any access to local infrastructure like shops or cafés, but may be well integrated into neighbourhood communities and may also participate in political activism regarding their neighbourhood. We can, hence, understand socio-spatial exclusion rather as a dynamic continuum than as a fixed status. Such a perspective results in a differentiating look at exclusion, both in terms of quality and quantity. Hence, some older adults might be "more excluded"; however, this does not necessarily equal being excluded in more dimensions. This might also suggest using other terms than "exclusion," which place more emphasis on its gradual nature, like deprivation.

Beyond its gradual nature, exclusion is also processual. It is particularly Lefebvre's theory of urban development that elaborates on the dynamic and co-constructive processes that "make places," involving everyday practices of spatial appropriation, cognitive perceptions of space and its (powerful) representations. Again, we can borrow the notion of intersectionality to speak of an intersection between practices of place appropriation, place perception and representation at which different forms of socio-spatial exclusion are constructed, reproduced or deconstructed. Taking this into account requires reflexivity in one's own research practice, questioning one's own approaches, methods and assumptions, and also challenging notions dominant in one's scientific field.

Finally, what kind of research agenda can be derived from a socialconstructionist, processual and intersectionalist perspective of sociospatial exclusion? Critical researchers working in the field of ageing 
Rethinking concepts of socio-spatial exclusion in later life

Table 1. A future research agenda for environmental gerontology

\begin{tabular}{|c|c|c|}
\hline Dimension & Agenda & Examples \\
\hline Research & $\begin{array}{l}\text { How do intersections } \\
\text { of age with income, } \\
\text { education, gender, } \\
\text { ethnicity, sexuality, } \\
\text { health, and residential } \\
\text { conditions relate to } \\
\text { different forms and } \\
\text { degrees of socio-spatial } \\
\text { deprivation? }\end{array}$ & $\begin{array}{l}\text { Which intersectionalities are } \\
\text { behind different socio-spatial } \\
\text { segregation processes (e.g. like } \\
\text { gentrification)? Which role does } \\
\text { age play in them? } \\
\text { - How does the intersection } \\
\text { of age and territorial stigma } \\
\text { influence old-age identities and } \\
\text { images of self? } \\
\text { - Under which conditions do } \\
\text { which dimensions of socio- } \\
\text { spatial exclusion intersect, and } \\
\text { where can we find spaces of } \\
\text { possibility? }\end{array}$ \\
\hline Reflection & $\begin{array}{l}\text { In how far does our } \\
\text { own research contribute } \\
\text { to the construction, } \\
\text { reproduction or } \\
\text { destruction of socio- } \\
\text { spatial exclusion? }\end{array}$ & $\begin{array}{l}\text { Which groups, social situations } \\
\text { and life-worlds do we make } \\
\text { visible and invisible through } \\
\text { our concepts, questions, } \\
\text { methods and samples? How } \\
\text { do we portray, label and - } \\
\text { potentially - stigmatize them? } \\
\text { - Which implications do the } \\
\text { concepts we use, and their } \\
\text { theoretical traditions, have? } \\
\text { Do they, for example, impose } \\
\text { criteria for successful or active } \\
\text { ageing, and hence implicitly } \\
\text { devaluate those who do not } \\
\text { meet these criteria? }\end{array}$ \\
\hline Implementation & $\begin{array}{l}\text { Which practical } \\
\text { implications can } \\
\text { we draw without } \\
\text { constructing new or } \\
\text { reproducing "old" } \\
\text { forms of socio-spatial } \\
\text { exclusion? }\end{array}$ & $\begin{array}{l}\text { - How can we cater for the } \\
\text { housing needs of, for example, } \\
\text { gay men, in later life? } \\
\text { Which concepts can we develop } \\
\text { beyond age-friendly cities to } \\
\text { establish planning ideas for } \\
\text { demographic change? }\end{array}$ \\
\hline
\end{tabular}


International Journal of Ageing and Later Life

studies, like Phillipson (2004, 2007), have shown what such a critical and reflexive research agenda for socio-spatial exclusion in later life may look like with their discussion of "age-friendly cities" (Buffel 2015; Buffel et al. 2012). In their recent "manifesto" for change, Buffel et al. (2018) demand an intensification in the participation of older adults, stakeholders and multidisciplinary research teams to further develop the age-friendly agenda. Acknowledging the call for a "participatory turn" in the practice of the age-friendly movement, our complementary approach calls for a "reflexive turn": hence, we propose intensifying not the involvement with the practice of age-friendly cities and communities, but its theorising, going even deeper into sociological theory, critique and reflexivity. Such an agenda might touch upon research, its reflection and - as gerontology has always been an applied discipline - implementation, and entail a range of questions, as portrayed in Table 1. To follow such an agenda, a new generation of environmental gerontologists might deploy theories from different disciplines and regional research traditions, thus broadening the horizon for understanding mechanisms of socio-spatial exclusion in later life.

\section{Acknowledgements}

This article is inspired by discussions from the "Community/Spatial Working Group (WG)" of the COST-financed Research Network "Reducing Old-Age Exclusion: Collaborations in Research and Policy" (ROSENet). The collaboration of the authors has been made possible through this research network as well. For further details on ROSENet, see: www.rosenetcost.com.

\section{Corresponding Author}

Anna Wanka, Institute of Social and Adult Education, Goethe University Frankfurt on the Main, Dantestrasse 9, D-60629 Frankfurt am Main, Germany. Email: wanka@em.uni-frankfurt.de.

\section{References}

Authier, J.-Y., Bacqué, M.-H. \& Guérin-Pace, F. (2006). Le Quartier [Neigborhood]. Paris: La Découverte. 
Baykara-Krumme, H., Schimany, P. \& Motel-Klingebiel, A. (eds.). (2012). Viele Welten des Alterns. Wiesbaden: VS Verlag für Sozialwissenschaften.

Bourdieu, P. (2015). Die verborgenen Mechanismen der Macht. Schriften zu Politik and Kultur. Hamburg: VSA-Verlag [1992].

Buffel, T. (2015). Researching Age-Friendly Communities. Stories from Older People as Co-Investigators. Manchester: The University of Manchester Library.

Buffel, T., Handler, S. \& Phillipson, C. (eds.). (2018). Age-Friendly Cities and Communities: A Global Perspective. Bristol: Bristol University Press.

Buffel, T., Phillipson, C. \& Scharf, T. (2012). Ageing in urban environments: Developing "age-friendly" cities. Critical Social Policy 32(4): 597-617.

Carp, F. M. (1987). Environment and aging. In D. Stokols \& I. Altman (eds.), Handbook of Environmental Psychology (pp. 330-360). New York: Wiley.

Cresswell, T. (2004). Place: A Short Introduction. Oxford: Blackwell.

Crenshaw, K. (1989). Demarginalizing the intersection of race and sex: A black feminist critique of antidiscrimination doctrine, feminist theory and antiracist politics. University of Chicago Legal Forum 1(8): 139-167.

Day, R. (2010). Environmental justice and older age: Consideration of a qualitative neighbourhood-based study. Environment and Planning $A$ 42: 2658-2673.

Di Méo, G. (2007). Identités et territoires: des rapports accentués en milieu urbain ? [Identity and territories: Exacerbed relations in urban area?]. Métropoles (1): 1-14.

Di Méo, G. \& Buléon, P. (2005). L'espace Social: Lecture Géographique Des Sociétés. Paris: Armand Colin.

Dowd, J. J. \& Bengtson, V. L. (1978). Aging in minority populations an examination of the double jeopardy hypothesis. Journal of Gerontology 33(3): 427-436.

Elias, N. \& Scotson, L. J. (1994). The Established and the Outsiders (2nd ed.). Thousand Oaks, CA: Sage.

Estes, C., Biggs, S. \& Phillipson, C. (2003). Social theory, Social Policy and Ageing: A Critical Introduction. London: Open University Press.

Friedrichs, J. (1988). Soziologische Stadtforschung. Wiesbaden: VS Verlag für Sozialwissenschaften. 
International Journal of Ageing and Later Life

Geiling, H. (ed.) (2003). Probleme Sozialer Integration: Agis-Forschungen Zum Gesellschaftlichen Strukturwandel, Soziale Milieus im Gesellschaftlichen Strukturwandel. Münster: Lit.

Goffman, E. (1986). Stigma: Notes on the Management of Spoiled Identity. New York: Simon and Schuster [1963].

Golant, S. M. (2015). Residential normalcy and the enriched coping repertoires of successfully aging older adults. The Gerontologist 55: 70-82.

Greenfield, E. A., Black, K., Buffel, T. \& Yeh, J. (2018). Community gerontology: A Framework for research, policy, and practice on communities and aging. The Gerontologist, gny089. doi: 10.1093/geront/gny089

Handler, S. (2014). An Alternative Age-Friendly Handbook. Manchester: The University of Manchester Library.

Häußermann, H. \& Siebel, W. (2000). Wohnverhältnisse und Ungleichheit. In A. Harth, G. Scheller \& W. Tessin (eds.), Stadt Und Soziale Ungleichheit (pp. 120-140). Wiesbaden: VS Verlag für Sozialwissenschaften.

Havighurst, R. J. (1976). Developmental Tasks and Education. New York: McKay.

Havighurst, R. J. (1954). Flexibility and the social roles of the retired. The American Journal of Sociology 59(4): 309-311.

Holland, C., Clark, A., Katz, J. \& Peace, S. (eds.). (2007). Social Interactions in Urban Public Places. Public spaces series. York: Joseph Rowntree Foundation.

Hoyt, G. C. (1954). The life of the retired in a trailer park. American Journal of Sociology 59(4): 361-370.

Kahana, E. (1982). A congruence model of person-environment interaction. In M. P. Lawton, B. C. Windley \& T. O. Byerts (eds.), Aging and the Environment: Theoretical Approaches (pp. 97-120). New York: Garland Publishing.

Keating, N., Eales, J. \& Phillips, J. E. (2013). Age-friendly rural communities: Conceptualizing "best-fit." Canadian Journal on Aging / La Revue Canadienne Du Vieillissement 32(4): 319-332.

Kelling, G. L. \& Wilson, J. Q. (1982). Broken windows: The police and neighbourhood safety. Atlantic Monthly 249: 29-38.

Keim, R. \& Neef, R. (2000). Ausgrenzung und Milieu: Über die Lebensbewältigung von Bewohnerinnen und Bewohnern städtischer Problemgebiete. In A. Harth, G. Scheller \& W. Tessin (eds.), Stadt 
Rethinking concepts of socio-spatial exclusion in later life

Und Soziale Ungleichheit (pp. 248-273). Wiesbaden: VS Verlag für Sozialwissenschaften.

Kennedy, M. \& Leonard, P. (2001). Dealing with neighbourhood change: A primer on gentrification and policy choices. Washington, DC: Brookings Institution.

Koceva, M. M., Brandmueller, T., Lupu, I., Oennerfors, Å., CorselliNordblad, L., Coyette, C., Johansson, A., Strandell, H., Wolff, P. \& European Commission (eds.). (2016). Urban Europe: Statistics on Cities, Towns and Suburbs. Luxembourg: Publications Office of the European Union.

Künemund, H. \& Kaiser, C. (2011). Das verborgene Verschwinden des Privaten in der zweiten Lebenshälfte. In K. Hahn \& C. Koppetsch (eds.), Soziologie des Privaten (pp. 303-311). Wiesbaden: VS Verlag für Sozialwissenschaften.

Lawton, M. P. (1989). Environmental proactivity in older people- In: V. L. Bengtson \& K. W. Schaie (eds.), The Course of Later Life (pp. 15-23). New York: Springer Pub. Co.

Lawton, M. P. \& Nahemow, L. (1973). Ecology and the aging process. In C. Eisdorfer \& M. P. Lawton (eds.), The Psychology of Adult Development and Aging (pp. 619-674). Washington, DC: American Psychological Association.

Lefebvre, H. (1991). The Social Production of Space [La production de l'espace]. Oxford: Blackwell. [1974]

Lindsley, O. R. (1964). Direct Measurement and prosthesis of retarded behavior. Journal of Education 147: 62-81.

Löw, M., Steets, S. \& Stoetzer, S. (2007). Einführung in die Stadt- und Raumsoziologie. Opladen: Budrich.

Lui, C.-W., Everingham, J.-A., Warburton, J., Cuthill, M. \& Bartlett, H. (2009). What makes a community age-friendly: A review of international literature. Australasian Journal on Ageing 28(3): 116-121. doi: 10.1111/j.1741-6612.2009.00355.x

Marchal, H. (2017). Le village Dans la Ville: l'expérience d'un Quartier Qui Fait Territoire et Lieu [The village in the city: Experience of a neighbourhood making territory and place]. Retraite et Société 76: 67-88. Available on https:/ / www-cairn-info.inshs.bib.cnrs.fr/ revue-retraiteet-societe-2017-1-page-67.htm 
International Journal of Ageing and Later Life

McCann, M., Grundy, E. \& O’Reilly, D. (2014). Urban and rural differences in risk of admission to a care home: A census-based follow-up study. Health and Place 30: 171-176.

Moulaert, T. \& Garon, S. (2015). Researchers behind policy development: Comparing "age-friendly cities" models in Quebec and Wallonia. Journal of Social Work Practice 29(1): 23-35. doi: 10.1080/02650533.2014. 993946

Moulaert, T. \& Garon, S. (eds.). (2016). Age-Friendly Cities in International Comparison: Political Lessons, Scientific Avenues, and Democratic Issues. New York: Springer, coll. International Perspectives on Aging, 14.

Moulaert, T., Wanka, A. \& Drilling, M. (2018). The social production of age, space and exclusion: Towards a more theory-driven understanding of spatial exclusion mechanisms in later life. Sociální studia/Social Studies.

Norman, A. (1985). Triple jeopardy: Growing old in a second homeland. London: Centre for Policy on Ageing.

Pereira, V. B. \& Queirós, J. (2014). "It's not a Bairro, is it?": Subsistence sociability and focused avoidance in a public housing estate. Environment and Planning A 46: 1297-1316.

Phillipson, C. (2011). Developing age-friendly communities: New approaches to growing old in urban environments. In S. Settersten \& J. Angel (eds.), Handbook of Sociology of Aging (pp. 279-293). New York: Springer.

Phillipson, C. (2007). The "elected" and the "excluded": Sociological perspectives on the experience of place and community in old age. Ageing and Society 27(03): 321-342. doi: 10.1017/S0144686X06005629

Phillipson, C. (2004). Urbanisation and ageing: Towards a new environmental gerontology. Ageing and Society 24: 963-972.

Plouffe, L., Kalache, A. \& Voelcker, I. (2016). A critical review of the WHO age-friendly cities methodology and its implementation. In T. Moulaert \& S. Garon (eds.), Age-Friendly Cities and Communities in International Comparison (pp. 19-36). New York: Springer.

Purcell, M. (2003). Citizenship and the right to the global city: Reimagining the capitalist world order. International Journal of Urban and Regional Research 27(3): 564-590.

Rowles, G. D. \& Watkins, J. F. (2003). History, habit, heart and hearth: On making spaces into places. In K. W. Schaie, H.-W. Wahl, H. Mollenkopf \& F. Oswald. (eds.), Aging Independently: Living Arrangements and Mobility (pp. 77-96). New York: Springer. 
Rethinking concepts of socio-spatial exclusion in later life

Sampson, R. J. (2009). Disparity and diversity in the contemporary city: Social (dis)order revisited. The British Journal of Sociology 60: $1-31$.

Sassen, S. (2014). Expulsions: Brutality and Complexity in the Global Economy. Cambridge, MA: The Belknap Press of Harvard University Press.

Savage, M., Warde, A. \& Ward, K. (2003). Urban Sociology, Capitalism and Modernity. Houndmills, Basingstoke, Hampshire, New York: Palgrave Macmillan.

Scharf, T. (2002). Growing Older in Socially Deprived Areas: Social Exclusion in Later Life. London: Help the Aged.

Simmel, G. (2010). The metropolis and mental life. In G. Bridge \& S. Watson (eds.), The Blackwell City Reader (pp. 11-19). Chichester; Malden, MA: Wiley-Blackwell. [1903].

Townsend, P. (2002). Poverty, social exclusion and social polarisation: The need to construct an international welfare state. In P. Townsend \& D. Gordon (eds.), World Poverty: New Policies to Defeat an Old Enemy (pp. 3-24). Bristol: Policy Press.

Townsend, P. (1979). Poverty in the United Kingdom. London: Allen Lane and Penguin Books.

United Nations, Department of Economic and Social Affairs, Population Division. (2018). World Urbanization Prospects: The 2018 Revision.

Vuaillat, F. \& Madoré, F. (2010). Une affaire de générations: la construction d'un entre-soi à l'épreuve de la mixité intergénérationnelle [A matter of generations: Constructing the self-proximity through intergenerational mix]. EspaceTemps.net. Available on https://www.espacestemps.net/ articles/mixite-intergenerations/

Wacquant, L. (2011). Territorial Stigmatisation Revisited: Symbols, State, and Space. Keynote address to the International Conference on Territorial Stigmatisation and Advanced Marginality, University of Porto, 22 June.

Wacquant, L., Slater, T. \& Pereira, V. B. (2014). Territorial stigmatisation in action. Environment and Planning A 46: 1270-1280.

Wahl, H.-W. \& Oswald, F. (2010). Environmental perspectives on ageing. In C. Phillipson \& D. Dannefer (eds.), The SAGE Handbook of Social Gerontology (pp. 111-124). London: Sage Publications Ltd.

Wahl, H.-W. \& Lang, F. R. (2006). Psychological aging: A contextual view. In P. M. Conn (ed.), Handbook of Models for Human Aging (pp. 881-895). New York: Elsevier. 
International Journal of Ageing and Later Life

Wahl, H.-W. \& Weisman, G. D. (2003). Environmental gerontology at the beginning of the new millennium: Reflections on its historical, empirical, and theoretical development. The Gerontologist 43: 616-627.

Wahl, H.-W., Mollenkopf, H. \& Oswald, F. (eds.) (1999). Alte Menschen in ihrer Umwelt: Beiträge zur ökologischen Gerontologie. Opladen: Westdeutscher Verlag.

Walsh, K., Scharf, T. \& Keating, N. (2017). Social exclusion of older persons: A scoping review and conceptual framework. European Journal of Ageing 14(1): 81-98. doi: 10.1007/s10433-016-0398-8

Wanka, A., Wiesböck, L., Allex, B., MAyrhuber, E., Arnberger, A., Eder, R., Kutalek, R., Wallner, P., Hutter, H.-P. \& Kolland, F. (2018). Everyday discrimination in the neighbourhood: What a 'doing' perspective on age and ethnicity can offer. Ageing and Society 1-26. doi: 10.1017/ S0144686X18000466

Wanka, A. (2018a). Disengagement as withdrawal from public space: Rethinking the relation between place attachment, place appropriation, and identity-building among older adults. The Gerontologist 58(1): 130-139.

Wanka, A. (2018b). Everyday discrimination in the neighbourhood. What a "doing" perspective on age and ethnicity can offer. Ageing and Society 2018.

Warf, B. \& Arias, S. (eds.). (2009). The Spatial Turn: Interdisciplinary Perspectives. Abingdon, Oxon and New York: Routledge.

Werthman, C. \& Piliavin, I. (1967). Gang members and the police. In D. Bordua (ed.), The Police: Six Sociological Essays (pp. 56-98). New York: Wiley.

White, S. \& Hammond, M. (2018). From representation to active ageing in a Manchester neighbourhood: Designing the age-friendly city. In Buffel, T., Handler, S. \& Phillipson, C. (eds.), Age-Friendly Cities and Communities: A Global Perspective (pp. 193-210). Bristol: Bristol University Press.

Wiles, J. L., Leibing, A., Guberman, N., Reeve, J. \& Allen, R. E. S. (2012). The meaning of "aging in place" to older people. The Gerontologist 52(3): 357-366. 
World Health Organization (WHO). (2007). Global Age-friendly Cities: A Guide. Geneva: WHO.

Young, M. \& Willmott, P. (1957). Family and Kinship in East London. London: Routledge and Kegan Paul. 